\title{
Park And Ride Facilities within Kuala Lumpur Conurbation: How willing are private vehicle commuters to use?
}

\author{
Anis Adibah Ibrahim 1, Norlida Abdul Hamid 2, Azimah Daud 1 \\ ${ }^{1}$ Faculty of Business \& Management, ${ }^{2}$ Arshad Ayub Graduate Business School \\ Universiti Teknologi MARA (UiTM), 40450 Shah Alam, Selangor Darul Ehsan, Malaysia \\ anisadibah.@gmail.com, norlida054@uitm.edu.my, azimah348@uitm.edu.my \\ Tel: +60133746541
}

\begin{abstract}
The rapid transformation of Kuala Lumpur conurbation has seen a rise in the demand for private vehicle ownership among commuters, thus leading to an increase in the overall level of congestion within the city center. Towards reducing such issues and focusing on the significance of travel demand management, this study examined the willingness of private vehicle users in using the park and ride facilities. A convenience survey was conducted on 199 respondents through multiple linear regression. It was found that socioeconomic, trip, and technology characteristics have a significant relationship with a willingness to park and ride. The result may assist future transport planners in improving the overall parking management strategies of the city centre.
\end{abstract}

Keywords: Willingness, park and ride, Kuala Lumpur conurbation, regression

eISSN: 2398-4287 @ 2019. The Authors. Published for AMER ABRA cE-Bs by e-International Publishing House, Ltd., UK. This is an open access article under the CC BYNC-ND license (http://creativecommons.org/licenses/by-nc-nd/4.0/). Peer-review under responsibility of AMER (Association of Malaysian Environment-Behaviour Researchers), ABRA (Association of Behavioural Researchers on Asians) and cE-Bs (Centre for Environment-Behaviour Studies), Faculty of Architecture, Planning \& Surveying, Universiti Teknologi MARA, Malaysia.

DOI: https://doi.org/10.21834/e-bpj.v4i12.1943

\subsection{Introduction}

Transportation Demand Management (TDM) or Mobility Management/Travel Demand Management is one of the strategies that affect the efficiency of the use of transportation resources (Victoria Transport Policy Institute, 2014). TDM is an action aimed at influencing people's travel behavior, such as switching to alternatives to single-occupant automobiles and measures towards reducing congestion. Activities typically consist of a mix of incentives and disincentives to make public transport, walking, cycling, and travel substitution more attractive (Venter \& Schnackenberg, 2015). Park and ride schemes are one of the Travel Demand Management (TDM) schemes that are popular in the congested city with a wide parking area at the borderline or outskirt areas of the city centre. This strategy aims at reducing peak period vehicle travel, reduces road and parking costs in the urban centre, reduces travel expenses, improves transit as travel choice, and also encourages urban expansion (Victoria Transport Policy Institute, 2014; Buchari, 2015). Such a scheme has been applied in many developed countries and cities as a means of transportation management of which its primary purpose is to encourage the transfer of transportation mode as well as to attract travellers to shift from being car users to bus passengers by providing competent services (Ying and Xiang, 2009).

According to Spillar (1997), park and ride scheme has existed in the forms of private cars to high occupancy vehicles, light rapid transit, mass rapid transit, commuter rail system and also ferry services. In Australia, the park and ride have schemes become an essential scheme to prompt public transport usage in Australian cities. It has become part of the urban landscape, especially concerning travel on demand (Olaru et al., 2014). Rail based park and ride are commonly established to mitigate traffic congestion that occurs in

eISSN: 2398-4287 @ 2019. The Authors. Published for AMER ABRA cE-Bs by e-International Publishing House, Ltd., UK. This is an open access article under the CC BYNC-ND license (http://creativecommons.org/licenses/by-nc-nd/4.0). Peer-review under responsibility of AMER (Association of Malaysian Environment-Behaviour Researchers), ABRA (Association of Behavioural Researchers on Asians) and cE-Bs (Centre for Environment-Behaviour Studies), Faculty of Architecture, Planning \& Surveying, Universiti Teknologi MARA, Malaysia. DOI: https://doi.org/10.21834/e-bpj.v4i12.1943 
the town centre, where the usage of public transport should be encouraged. In Canberra, a study found out that $98 \%$ of the respondents parked their cars and rode the bus as part of their journey, while $73 \%$ of the respondents switch from a car (Islam et al., 2015).

Park and ride have started in Shanghai, China, and Hong Kong, where it aims to promote the park and ride opportunity by implementing comprehensive policies and measures. Since the success of the first trial run of the park and ride scheme by the KowloonCanton Railway Corporation (KCRC), Sheng Shui in Hong Kong in 1997, the system has since been in operation (Lam et al., 2001). The current policies of the park and ride in China mainly focus on demand forecasting, distribution planning, and facility location and benefit assessment (Ying \& Xiang, 2009). The survey conducted by Ying and Xiang (2009) stated that 50\% of the people expressed their willingness to choose a park and ride, and the rest said they are not interested in adopting the park and ride. The leading causes of their unwillingness to park and ride were due to crowded public transit vehicles, inconvenience to return, carrying heavy things, and business needs. There are two roles of transfers. Firstly, the shift increases the accessibility of various destinations for users (e.g., on city streets where the limited entry for private vehicles). Secondly, is the interchange that facilitates transfers provided in-network at strategic locations to decrease the duplication of public transport routes (Chowdhury \& Ceder, 2016).

Like many other fast developing cities in the world, traffic congestion is still a continuous issue affecting the city of Kuala Lumpur. For this, the Urban Public Transport New Key Results Area (UPT NKRA) was implemented under the Ministry of Transport Malaysia to fix the flaw in public transport by implementing two main criteria namely Government Transformation Program (GTP) 1.0 and GTP 2.0 where both focused towards enhancing the overall transport system. For the rail system, in particular, the initiatives include improving the capacity of the rail system as well as strengthening the integration of the urban public transport system. However, statistics have indicated that there is an issue affecting the utilization of the park and ride facilities within the city centres. This includes cases of underutilization of some stations (Prasarana, 2017), including that of Subang station and Taman Bahagia stations (among others). Even though there are around 19,697 parking bays, including the new MRT project that was built from 2015 till today, the problem of underutilization still occurs, and the target yet has not been achieved. Other issues include that of security affecting stations like Kelana Jaya, Asia Jaya, Taman Paramount, and Subang Jaya (The STAR Online, 2017). Apart from socioeconomic issue of Malaysia including Kuala Lumpur sees of the increase in its cost of living (The Rakyat Post, 2019), other issues affecting the use of the facility include that of the rise in the facility parking charges as some users are unwilling to pay for the parking charges (Stieffenhofer et al., 2016), trip cost and the number of transfers to be made (Olaru et, al. 2014; Lee \& Hickman, 2014) as well as technology characteristics such as that of online information (Julsrud \& Denstadli, 2017; Jamal et al., 2017).

Accordingly, this study aimed to examine the willingness of the city commuters' private vehicle users to adopt and use the park and ride facilities within Kuala Lumpur conurbation. This study analyzed the extent of the relationship of socioeconomic characteristics, parking characteristics, trip characteristics, and technology characteristics with their willingness to park and ride, on their trips to work in the city centre. The analysis further examined, which among the independent variables, gives the most influence towards the variance of the willingness to park and ride.

The objective of the study is to examine the determinants of the willingness to park and ride among the private vehicle users of Kuala Lumpur conurbation, to measure the extent of relationship between the elements of socioeconomics, parking, trip and technology characteristics with the willingness to park and ride among the private vehicle users of Kuala Lumpur conurbation and to examine the dimension that gives the most influence on the variance of the desire to park and ride among the private vehicle users of Kuala Lumpur conurbation.

\subsection{Literature Review}

Nordlund \& Westin (2013) stated that values, beliefs, and age are related to the intention to use the train services, and most youngsters prefer to choose a train compared to early middle age and pensioners. Similarly, a study by Rose \& Hensher (2007), middle-aged commuters are inclined to drive more due to family obligations, financial, and mobility restrictions. Based on the survey by Krygsman \& Dijst (2001), income has a moderate and variable effect on the utilization of the facility. In a field study conducted by Shiftan et al., (2003) and Rose \& Hensher (2007), commuters with higher income prefer to drive rather than use public transport. This, however, differs from the findings by Hamid (2009), whereby the users from the middle-income group (RM2,000 - RM3,999) indicated their affordability for the demand and use of the facility as compared to the lower-income group. Based on this, Hamid et al., (2007) revealed that there is a significant relationship between income and utilization of park and ride facility, at a p-value of 0.000 , at $95 \%$ confidence interval.

Hamsa et al., (2014) stated that the survey conducted in 2014 showed that the parking usage in Kelana Jaya LRT station has a $92 \%$ of parking occupancy rate. Besides, the study carried out by Adnan et al., (2015) indicated that the Putrajaya park and ride facility had a 95\% parking occupancy rate and also noted that vehicles had parked illegally at the parking surface. In terms of cost, Adnan et al., (2015) findings concluded that the direct cost of rail fare and parking charges could influence the mode of transportation chosen. According to Faghri et al., (2002), park and ride should be located far from the city's primary activity centre, also identified as Central Business District (CBD) in the urban area. However, in some metropolitan regions, multiple activity centres will be in the running for a park and ride facilities. The place that has convenient access and high visibility are more in the high necessity to be chosen for the location, especially near highways interchanges (Faghri et al., 2002). Also, the survey conducted by Rathbone (2006) indicated that $70 \%$ of 24 transit agencies that have the most successful park and ride facilities must be within half a mile of a major highway.

The main factors that attracted the users of the park and ride were the monetary and time-saving (Lam et al., 2001). This finding is supported by the works of Bos et al., (2004), whereby the study found that the willingness of private vehicle users to use the park and ride facilities will increase if the travel time is decreased. On the other hand, Borhan et al., (2011) found that more than half of the respondents $(58 \%)$ agreed to use the park and ride facility if their total travel time can be saved when using the facility. The stress is 
attributed to the bottleneck congestion they face that lead to the delay in reaching the destination. From the same study by Hamid et al., (2007), it was found that a total of $54.2 \%$ of the respondent commuters did not make any transfer to their destination but only by walking at the egress station. Also, the respondents experienced a seamless journey since no transfers made from origin to the destination.

The research was done by Julsrud \& Denstadli (2017) on socioeconomic factors clarified that around $80 \%$ of travellers usually carry a smartphone or other devices on public transport, with $2 \%$ did not have any communication devices on their trip and $90 \%$ in the age group of below 30 are equipped with a smartphone. An additional to research by Jamal et al., (2017) analyzed that $77.72 \%$ of smartphone users have no impact on vehicle kilometres travelled. The reason for higher use is that smartphone applications are used more for online shopping, and that has increased the possibility of a reduction in vehicle kilometres went. The drivers' decision to move could be influenced by the information about road traffic conditions. Upon receiving congestion information, drivers are likely to change their departure time (Khoo \& Ong, 2011) or divert to alternatives routes (Yim et al., 2002) to enjoy travel time saving and stress-free driving.

\subsection{Methodology}

In terms of research design, the primary research strategy is survey while the unit of analysis is individual (all private vehicle users who have their final trips into the city centre, used their private vehicles to work and have access to the park and ride facilities at both origin and destination). A personally administered survey was conducted with the primary objective of examining the nature of the relationships of the related variables with the willingness to park and ride among the private vehicle users of Kuala Lumpur conurbation, especially in the Golden Triangle, as per Figure 1. The instrument used for the survey was that of a structured questionnaire, with 5-point Likert scale items that consisted of four main components, namely socioeconomic, parking, trip, and technology characteristics that adapted from past research study except for technology (new variables). The scale ranged from 'strongly disagree' to 'strongly agree'. The questionnaires were distributed on weekdays and weekends at private vehicle parking areas in Golden Triangle. Using a convenience sampling technique, a total of 199 valid questionnaires were gathered. Before the actual survey, a pretest was done on selected industry experts to gauge the validity of the instrument used. A pilot test was also carried on 30 respondents to identify potential problem areas and deficiencies in the research instruments and protocol before the implementation of the full study. In terms of the inferential data analysis, multiple regression analysis was used to predict which of the independent variables give the most influence on the variance of the dependent variable.

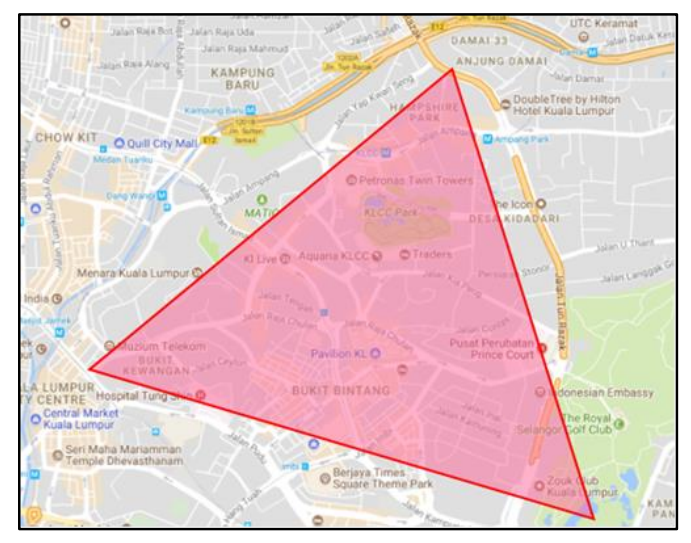

Fig. 1 Study area - Golden Triangle of Kuala Lumpur conurbation Source: Google Maps (2019)

\subsection{Findings}

Table 1 shows the frequency of the demographic output of the research. The table shows the frequency analysis of demographic factors or socioeconomic characteristics for a total of 199 respondents involved in this survey. Based on the study conducted, it was found that most of the respondents were female, which made up 61.5\% (123), while the remaining respondents that made up 38.5\% (77) were male. Most of the respondents were from the survey age group of 54 years and above. This group made up a total of $21 \%$ (42) followed by the age group of $30-35$ years old that made up $16.5 \%$ (33) of the total respondents, and next is the age group of 48-53 years old made up $15 \%(30)$. The majority of the respondents $(68.5 \%, 137)$ were married, while $31.5 \%(63)$ were single. In terms of monthly income, the highest income among the respondents were those in the income group of RM5000 to RM5999 $(32.5 \%, 65)$, followed by the income group of those between RM4000 to RM4999 (24.5\%, 49). Those with an income of between RM2000 to RM3999 made up the least group among the respondents, with $11.5 \%(23)$. In terms of private vehicle availability, most of the respondents have two vehicles that made up $42.5 \%$ (85). In contrast, $27.5 \%$ (55) have only one vehicle. A total of $18.0 \%$ of the total respondents (36) has three vehicles, while $12.0 \%(24)$ of the total respondents did not have any private vehicles owned. 
Table 1. Frequency of the demographic information

\begin{tabular}{|c|c|c|c|}
\hline Profile & Description & $\%$ & Frequency \\
\hline \multirow[t]{2}{*}{ Gender } & Male & 38.5 & 77 \\
\hline & Female & 61.5 & 123 \\
\hline \multirow[t]{7}{*}{ Age } & 18 to 23 years & 11.5 & 23 \\
\hline & 24 to 29 years & 12.0 & 24 \\
\hline & 30 to 35 years & 16.5 & 33 \\
\hline & 36 to 41 years & 14.5 & 29 \\
\hline & 42 to 47 years & 9.50 & 19 \\
\hline & 48 to 53 years & 15.0 & 30 \\
\hline & 54 years and above & 21.0 & 42 \\
\hline \multirow[t]{3}{*}{ Marital Status } & Single & 31.5 & 63 \\
\hline & Married & 68.5 & 137 \\
\hline & Others & 0 & 0 \\
\hline \multirow[t]{5}{*}{ Monthly Income } & Less than RM1999 & 14.5 & 29 \\
\hline & RM2000 to RM3999 & 11.5 & 23 \\
\hline & RM4000 to RM4999 & 24.5 & 49 \\
\hline & RM5000 to RM5999 & 32.5 & 65 \\
\hline & RM6000 and above & 17.0 & 34 \\
\hline \multirow[t]{5}{*}{ Private vehicles availability } & No vehicle & 12.0 & 24 \\
\hline & One & 27.5 & 55 \\
\hline & Two & 42.5 & 85 \\
\hline & Three & 0 & 0 \\
\hline & More than three & 18.0 & 36 \\
\hline \multirow[t]{4}{*}{ Employment category } & Government sector & 33.0 & 66 \\
\hline & Private sector & 47.0 & 94 \\
\hline & Self-employed & 17.5 & 35 \\
\hline & Others & 2.5 & 5 \\
\hline \multirow[t]{3}{*}{ Private vehicles frequency } & At least once a week & 36.5 & 73 \\
\hline & 2 to 3 times per week & 36.5 & 73 \\
\hline & More than 3 times per week & 27.0 & 54 \\
\hline \multirow[t]{2}{*}{ Public transport usage } & Yes & 78.0 & 156 \\
\hline & No & 22.0 & 44 \\
\hline \multirow[t]{4}{*}{ Public transport frequency } & Once a week & 14.5 & 29 \\
\hline & 1 to 2 times every 2 weeks & 27.0 & 54 \\
\hline & Rare & 36.5 & 73 \\
\hline & 0 & 22.0 & 44 \\
\hline
\end{tabular}

The result also shows the employment category from the private sector is the highest percentage, with $47.0 \%$ (94), followed by $33.0 \%$ (66) from the government sector. A total of $17.5 \%$ (35) of the respondents were self-employed, and a balance of $2.5 \%$ (5) were from others, such as students or unemployed. In terms of the frequency of the use of private vehicles to the city centre, the majority of the respondents, with a combined total of $73 \%(146)$, used their private vehicles at least once a week to the city center. The remaining $27.0 \%$ (54) have used their private vehicles more than three times per week for trips to the city center. As for public transport usage, the result indicated that $78.0 \%$ or 156 respondents stated that they had used public transport to their final destinations. In contrast, the remaining $22.0 \%$ (44 respondents) have not used public transport for trips to the city centre.

In terms of Cronbach's Alpha measure of reliability and based on Hair et al., (2003) table of reliability coefficient interpretation, the scores indicate that all variables achieve a range of between moderate and a good measure of internal consistency on the items being measured. Before the inferential analysis of multiple regression was conducted, testing of the related assumptions in terms of normality, linearity, homoscedasticity, outliers, and multicollinearity indicated no violation of any of the assumptions. Hence the multiple regression analysis was conducted on the scores.

Table 2. Model Summary

\begin{tabular}{ccccc}
\hline Model & $\mathrm{R}$ & $\mathrm{R}$ Square & Adjusted R Square & Std. Error of the Estimate \\
\hline 1 & $.635^{\mathrm{a}}$ & .403 & .391 & 5.16745 \\
\multicolumn{4}{c}{ Predictors: (Constant), Socioeconomic, Parking, Trip and Technology } \\
& \multicolumn{4}{c}{ Dependent Variable: Willingness to park and ride }
\end{tabular}

While the ANOVA result from this regression analysis indicates that this model reached statistical significance, Table 2 signifies the model summary. This model produces an R-square value of 0.403 , thus indicating that a total of $40.3 \%$ of the variance in the willingness of the park and ride users to park their vehicles at the nearby parking facility. It's explained by the four related characteristics, namely socioeconomic, parking, trip, and technology, assuming all other variables remain the same. The balance of $59.7 \%$ of the variance in the dependent variable is explained by other variables that are not covered in this research.

Table 3 further indicates that there is a significant positive relationship between socioeconomic characteristics $(B=0.38, p<0.05)$, trip characteristics $(B=0.578, p<0.05)$ as well as technology characteristics $(B=0.372, p<0.05)$, with the willingness of the private vehicle users to park and ride at the related facility. There is, however, no significant relationship between parking characteristics $(B=-0.079$, 
$p>0.05)$ and the willingness to park and ride among the private vehicle users. The table further explains that trip characteristics, with Beta $=0.392, p<0.05$ is the best predictor towards predicting the variance of the willingness to park and ride among the private vehicle users.

Table 3. Standardized Coefficient

\begin{tabular}{|c|c|c|c|c|c|c|c|c|c|c|c|c|}
\hline \multirow[t]{2}{*}{ Model } & \multicolumn{2}{|c|}{$\begin{array}{l}\text { Unstandardized } \\
\text { Coefficients } \\
\end{array}$} & \multirow{2}{*}{$\begin{array}{l}\text { Standardized } \\
\text { Coefficients } \\
\text { Beta }\end{array}$} & $t$ & \multirow{2}{*}{ Sig. } & \multicolumn{2}{|c|}{$\begin{array}{l}95.0 \% \text { Confidence Interval } \\
\text { for B }\end{array}$} & \multicolumn{3}{|c|}{ Correlations } & \multicolumn{2}{|c|}{ Collinearity Statistics } \\
\hline & $B$ & Std. Error & & & & Lower Bound & $\begin{array}{l}\text { Upper } \\
\text { Bound }\end{array}$ & $\begin{array}{l}\text { Zero- } \\
\text { order }\end{array}$ & Partial & Part & Tole & VIF \\
\hline (Constant) & 9.127 & 3.625 & & 2.517 & .013 & 1.977 & 16.277 & & & & & \\
\hline Socioeconomic & .38 & .088 & .225 & 3.954 & .000 & .174 & .522 & .348 & -.273 & .219 & .946 & 1.057 \\
\hline Parking & -.079 & .104 & -.050 & -.753 & .453 & -.285 & .127 & .287 & -.054 & -.042 & .691 & 1.447 \\
\hline Trip & .578 & .112 & .392 & 5.157 & .000 & .357 & .799 & .555 & .347 & .286 & .532 & 1.881 \\
\hline Technology & .372 & .100 & .249 & 3.712 & .000 & .174 & .507 & .488 & .258 & .206 & .683 & 1.463 \\
\hline
\end{tabular}

\subsection{Discussion}

This research has focused on the willingness of the private vehicle users of Kuala Lumpur conurbation in using the park and ride facilities that are available within the conurbation. In terms of the socioeconomic aspects, the result explains that a one-unit increase in the financial capability of the users will lead to an increase of 0.38 units of their willingness to use the park and ride facility. The fact that the majority of the respondents (a combined 73\%), at other times, have used public transport to go to work further indicates their desire to use public transport. As using the park and ride requires them to take the train as their primary mode to their final destinations, this gives an indication then on their willingness to use the park and ride facility. The work of Lindsey \& Verhoof (2001) supports this finding. In terms of trip characteristics, a one-unit increase in the trip characteristics such as flexible train schedules and the minimal number of interchanges or transfers will lead to a 0.578 unit increase among the respondents' willingness to park and ride. This nature of the relationship is perhaps expected as any train rider will rely and depend more on a relatively good and flexible train schedule to ensure that one arrives on time and punctual. The reliability of the train schedule also plays a vital role in any trip. These findings concur with that of the work of Hamid (2009), where the parameters affecting the use of park and ride include that of the level of integration among modes as well as parking charges. In terms of technology characteristics, with the advent of the digitalization era and the availability of many user-friendly apps developed by the related rail operators, a one-unit increase in the trip characteristics will lead to an increase of 0.372 units among the respondents' willingness to park and ride. The work of Julsrud \& Denstadli (2017) provides support for this factor. It is perhaps important to note that having a user-friendly app (technology) but not within the expected time of departure and arrival will certainly deter one from further using the train services. This will undoubtedly affect one's willingness to park and ride. There is, however, no significant positive relationship between parking characteristics and the willingness to park and ride among the private vehicle users. A one-unit increase in the rates of the parking charges, as well as the reduction in the parking spaces of the parking facility will lead to a decrease of 0.079 in the willingness of the respondents to park and ride. This is consistent with the work of Chen et al., (2015) as well as that of Holguin-Veras et al., (2012). Lack of parking spaces will undoubtedly deter the willingness of the park and ride users to park and ride in the future. The non-significant relationship between parking characteristics and the willingness to park and ride can be attributed to the fact that the current parking charges at the park and ride facilities are not low enough to attract potential parkers to use the facility. At the same time, those parking charges at the various parking lots in the city centre for private vehicles are not significantly high enough to deter private vehicle users from using the facilities.

\subsection{Conclusion and Recommendations}

Kuala Lumpur conurbation (KLC) is a large urban entity that centers Kuala Lumpur city center and is the most industrialized and economically fast-growing conurbation in the country. Findings from the study indicate that socioeconomic, trip, and technology characteristics show a significant relationship with the private vehicle users' willingness to park and ride at the related facilities within the conurbation. Examining the implementation of the park and ride facilities in Calgary (Canada) and Tyne and Wear (UK) (Buchari, 2015; Parkhurst, 2014), it has shown that the successfulness of the use of the facilities very much relies on the parking charges as well as the parking spaces. The annual price changes for on-street parking in the city centre and at the same time reducing the costs of the park and ride facility, flexibility in the pricing and supply for reserves parking and basic prices on occupancy, all have improved the customer targets to use the facilities. As for parking spaces, the extra parking spaces in the park and ride, such as the multi-story parking lots, might attract more potential users during peak and off periods. The parking spaces in the city centre can be reduced while the parking spaces in the park and ride can be very abundant, encouraging more users to use the park and ride facilities. Since these factors are critical in influencing the private vehicle users' willingness to park and ride, hence more in-depth understanding of these factors is both essential and crucial for more effective planning of such facilities in the future. Ultimately, planners and decision-makers need to ensure that there is worthiness in the investment on the related projects. 


\subsection{Limitation of the study and future research}

This study location is limited within the Kuala Lumpur conurbation region only with a relatively small sample size of 199 valid respondents. Future research on this area may consider other urban areas with relatively high traffic volume such as Penang, Ipoh, and Johor Bahru using a larger sample size.

\section{Acknowledgements}

We would like to express our gratitude to Universiti Teknologi MARA (UiTM) for the support given in completing this study. An appreciation goes as well to the staff of the rail operator, Prasarana Sdn. Bhd. for their continuous support in this survey.

\section{References}

Adnan, S. A. A. S., \& Hamsa, A. A. K. (2015). Factors Influencing the Parking Demand of the Park and Ride Facility at Putrajaya Public Transportation Terminal. Journal of the Eastern Asia Society for Transportation Studies, 11, 1291-1306

Buchari, E. (2015). Transportation demand management: a park and ride system to reduce congestion in Palembang city Indonesia. Procedia Engineering, $125,512-518$.

Borhan, M. N., Rahmat, R. A. A. O. K., Ismail, A., \& Ismail, R. (2011). Prediction of traveling behavior in Putrajaya, Malaysia. Research Journal of Applied Sciences, Engineering and Technology, 3(5), 434-439.

Bos, I. D., Van der Heijden, R. E., Molin, E. J., \& Timmermans, H. J. (2004). The choice of park and ride facilities: an analysis using a context-dependent hierarchical choice experiment. Environment and Planning A, 36(9), 1673-1686.

Chen, C., Xia, J. C., Smith, B., Olaru, D., Taplin, J., \& Han, R. (2015). Influence of parking on train station choice under uncertainty for park-and-ride users. Procedia Manufacturing, 3, 5126-5133.

Chowdhury, S., \& Ceder, A. A. (2016). Users' willingness to ride an integrated public-transport service: A literature review. Transport Policy, 48, 183-195

Faghri, A., Lang, A., Hamad, K., \& Henck, H. (2002). Integrated Knowledge-Based Geographic Information System for Determining Optimal Location of Park-and-Ride Facilities. Journal of Urban Planning and Development, 128(1), 18-41.

Hair Jr, J. F., Babin, B., Money, A. H., \& Samouel, P. (2003). Essentials of Business Research Methods: United States of America, Johns Wiley \& Sons. Inc.

Hamid, N. A. (2009). Utilization patterns of park and ride facilities among Kuala Lumpur commuters. Transportation, 36(3), 295-307.

Hamid, N. A., Mohamad, J., \& Karim, M. R. (2007). Parking duration of fringe park-and-ride users and delineation of stations catchment area: case of the Kuala Lumpur conurbation. In Proceedings of the Eastern Asia Society for Transportation Studies Vol. 6 (The 7th International Conference of Eastern Asia Society for Transportation Studies, 2007) (pp. 173-173). Eastern Asia Society for Transportation Studies.

Hamsa, A. K., Adnan, S. S., \& Khalid, U. (2014). Analysis of parking usage at the park and ride facility in Klang Valley, Malaysia. Urban Transport XX, $138,179$.

Holguin-Veras, J., Reilly, J., Aros-Vera, F., Yushimito, W., \& Isa, J. (2012). Park-and-ride facilities in New York City: economic analyses of alternative locations. Transportation Research Record, 2276(1), 123-130.

Islam, S. T., Liu, Z., Sarvi, M., \& Zhu, T. (2015). Exploring the mode change behavior of park-and-ride users. Mathematical Problems in Engineering, 2015.

Jamal, S., Habib, M. A., \& Khan, N. A. (2017). Does the Use of Smartphone Influence Travel Outcome? An Investigation on the Determinants of the Impact of Smartphone Use on Vehicle Kilometres Travelled. Transportation Research Procedia, 25, 2690-2704.

Julsrud, T. E., \& Denstadli, J. M. (2017). Smartphones, travel time-use, and attitudes to public transport services. Insights from an explorative study of urban dwellers in two Norwegian cities. International Journal of Sustainable Transportation, 11(8), 602-610.

Khoo, H. L., \& Ong, G. P. (2011). Analysis of awareness and use of traffic information system with revealed preference data: case study of Klang Valley, Malaysia. Transportation Research Record, 2239(1), 101-111.

Krygsman, S., \& Dijst, M. (2001). Multimodal trips in the Netherlands: Microlevel individual attributes and residential context. Transportation Research Record, 1753(1), 11-19.

Lam, W. H., Holyoak, N. M., \& Lo, H. P. (2001). How park-and-ride schemes can be successful in Eastern Asia. Journal of Urban Planning and Development, 127(2), 6378.

Lee, S. G., \& Hickman, M. (2014). Trip purpose inference using automated fare collection data. Public Transport, 6(1-2), 1-20.

Lindsey, C. R., \& Verhoef, E. T. (2000). Traffic congestion and congestion pricing (No. 00-101/3). Tinbergen Institute Discussion Paper.

Nordlund, A., \& Westin, K. (2013). Influence of values, beliefs, and age on intention to travel by a new railway line under construction in northern Sweden. Transportation Research Part A: Policy and Practice, 48, 86-95.

Olaru, D., Smith, B., Xia, J. C., \& Lin, T. G. (2014). Travellers' Attitudes Towards Park-and-Ride (PnR) and Choice of PnR Station: Evidence from Perth, Western Australia. Procedia-Social and Behavioral Sciences, 162, 101-110. 
Parkhurst, G., \& Meek, S. (2014). The effectiveness of park-and-ride as a policy measure for more sustainable mobility. In Parking issues and policies (pp. 185-211). Emerald Group Publishing Limited.

Prasarana Malaysia Berhad (2017). Prasarana Sets RM17 Billion in Economic Returns for 2017 Target - RapidKL, Malaysia. Retrieved 30 July 2017. https://www.myrapid.com.my/corporate-information/media/media-releases/prasarana-sets-rm17-billion-in-economic-returns-for-2017-target

Rathbone, D. (2006) Characteristics of the Most Successful Park-and Ride Lots in North America. The Urban Transport Monitor, Vol. 20, pp. 9-13

Rose, J. M. \& Hensher, D. A. (2007). Development of commuter and non-commuter mode choice models for the assessment of new public transport infrastructure projects: a case study. Transportation Research Part A: Policy and Practice, 41(5), 428-443.

Shiftan, Y., Ben-Akiva, M., Proussaloglou, K., de Jong, G., Popuri, Y., Kasturirangan, K., \& Bekhor, S. (2003, August). Activity-based modeling as a tool for better understanding travel behaviour. In 10th International Conference on Travel Behaviour Research (pp. 10-15).

Spillar, R. J. (1997). Park-and-Ride Planning and Design Guidelines. First Printing (p. 192)

Stieffenhofer, K. E., Barton, M., \& Gayah, V. (2016). Assessing Park-and-Ride Efficiency and User Reactions to Parking Management Strategies. Journal of Public Transportation, 19(4), 5 .

The Rakyat Post Online (June 27, 2019). KL is getting more expensive to live in rising 4 spots on world's most expensive cities list. Retrieved from June 20th, Thursday, 2017. https://www.therakyatpost.com/2019/06/27/kl-is-getting-more-expensive-to-live-in-rising-4-spots-on-worlds-most-expensive-cities-list/

The STAR Online (May 17, 2017) Park and ride facilities need improvement, say commuters. Retrieved from August $28^{\text {th }}$, Monday, 2017. https://www.thestar.com.my/metro/community/2017/08/28/parkandride-facilities-need-improvement-say-commuters-concerns-over-security-as-many-parking-lots-ar/

Venter, C. J., \& Schnackenberg, E. (2015) Travel Demand Management in Midland. Victoria Transport Policy Institute (2014) Online TDM Encyclopaedia

Victoria Transport Policy Institute (2014) Transportation Demand Management. Online TDM Encyclopaedia. Accesses November 20, 2018. https://www.vtpi.org/tdm/

Yim, Y., Khattak, A. J., \& Raw, J. (2002). Traveler response to new dynamic information sources: Analyzing corridor and areawide behavioral surveys. Transportation research record, 1803(1), 66-75.

Ying, H., \& Xiang, H. (2009, October). Study on influence factors and demand willingness of Park and Ride. In 2009 Second International Conference on Intelligent Computation Technology and Automation (Vol. 4, pp. 664-667). IEEE. 